\title{
Autochthonous Heritage Languages and Social Media: Writing and Bilingual Practices in Low German on Facebook
}

\begin{abstract}
:
This article analyses how speakers of an autochthonous heritage language (AHL) make use of digital media, through the example of Low German, a regional language used by a decreasing number of speakers mainly in northern Germany. The focus of the analysis is on Web 2.0 and its interactive potential for individual speakers. The study therefore examines linguistic practices on the social network site Facebook, with special emphasis on language choice, bilingual practices and writing in the autochthonous heritage language. The findings suggest that social network sites such as Facebook have the potential to provide new mediatized spaces for speakers of an AHL that can instigate sociolinguistic change.
\end{abstract}

Keywords: autochthonous heritage languages, Low German, mediatization, sociolinguistic change, writing, bilingual practices, translanguaging

\section{Introduction}

Can the media trigger or influence language change? This is a question to which, until fairly recently, the established linguistic answer would have been a negative one. Seen from a structuralist point of view, language as a system seems unlikely to be changed by the way it is used by the media. ${ }^{1}$ On the contrary, media such as newspapers, television or radio have very much been seen as institutions that uphold and promote national standard varieties (see, e.g., Chambers 1998; Labov 2001). More recently, two developments have led researchers to revisit this established point of view. Firstly, sociolinguistic approaches focusing on the communicative practices of individual speakers as agents of change have found that such speakers may indeed model the way they use language on the media. This process, referred to as mediatization (Androutsopoulos 2014; Coupland 2014; Hepp 2014; Krotz 2003, 2007, 2009), shapes the way that communication is carried out in various different media. Media themselves develop in ways that change and mould the way language is used. Changes in linguistic practices induced by developments in society, also referred to as sociolinguistic change (for an overview see Androutsopoulos 2014), can potentially also lead to language change; in fact, Coupland $(2014,74)$ argues that all forms of 
language change can be referred back to sociolinguistic change in the first instance. Secondly, the rise of computer-mediated communication (CMC) and especially the introduction of the more interactive technologies usually referred to as 'Web 2.0' have started to change general perceptions of 'the media' in linguistic research. We are currently witnessing forms of sociolinguistic change in connection with CMC, in some cases at a dramatic pace, which may in a number of cases lead to language change.

This article examines how speakers of heritage languages make use of digital media, through a case study of Low German, a regional language used by a decreasing number of speakers mainly in northern Germany. ${ }^{2}$ The term 'heritage language' is applied here to identify languages other than the dominant standard languages in a given social context. It can refer to immigrant heritage languages, where populations migrate to areas in which other languages form the dominant standard. In the context of this study, however, heritage language refers to one spoken by an indigenous or autochthonous population - Low German speakers - in contact with the dominant standard variety German. Autochthonous heritage languages (AHLs) ${ }^{3}$ in the twenty-first century tend to be endangered languages, since the communicative requirements of daily life are increasingly covered by the respective dominant standard language. In the case of Low German, a relatively stable diglossic set-up with Low German as the spoken and standard German as written language has been eroding since the 1960s. Research suggests that increasingly, an important function of AHLs for their speakers lies in their potential for identity work (see, e.g., Gardner-Chloros 2009; Thomason 2015), a tendency clearly observable for Low German, too (see, e.g., Reershemius 2009).

Maintenance efforts to create spaces and communicative domains for AHLs have been dominated until fairly recently by activists - individuals or organizations appealing to governments and institutions to grant legislation and language rights to preserve and expand the reach of AHLs, for example via media presence or education (see, e.g., Pietikäinen and Kelly-Holmes 2011). A direct connection between media presence of AHLs and language maintenance, however, is difficult to establish (see, e.g., Cormack 2007; Fishman 1991; Moring 2013). The advent of CMC, and especially the interactive opportunities of social media, now presents speakers of AHLs with the opportunity to create their own mediatized spaces where they can assume a far more active role than was previously the case (Deumert 2014; Kelly- 
Holmes 2014; Leggio 2011; Moriarty 2014; Pietikäinen 2014). Since the early 2000s, there have been discussions of the role that the Internet can play in maintenance efforts of AHLs facing the loss of communicative domains to more dominant languages, notably English. Researchers have pointed out both the challenges and the opportunities arising from CMC for smaller languages (see, e.g., Cunliffe and Herring 2005): although the Internet is the medium of globalized communication par excellence and thus a multiplier for majority languages, it also offers new opportunities for smaller languages. Roughly a decade ago, cautious optimism prevailed (Buszard-Welcher 2001; Hinton and Hale 2001). Some researchers expressed the view that effective use of CMC could be the mainstay of successful maintenance efforts in the future: 'An endangered language will progress if its speakers can make use of electronic technology' (Crystal 2000, 141). On the basis of an analysis of 50 websites on endangered languages, Buszard-Welcher (2001) states that the Internet helps to create online communities in which endangered languages are actively used, thus establishing new domains and modes of communication, in some cases including written varieties of previously spoken-only languages (see, e.g., Deuber and Hinrichs 2007; Leggio 2011, Matras 2013; Rajah-Carrim 2009). The presence of an AHL on the Internet can also show that it is an important part of modern life, which may be a factor in convincing younger speakers to maintain their AHL (Eisenlohr 2004; Jones, Cunliffe and Honeycutt 2013). A number of case studies on AHLs and their use on the Internet, published around the same time, came to similar conclusions (Mensching 2000; Ouakrime 2001; Warschauer 2002; Warschauer, El Said and Zohry 2002; Wiens 2000; Williams 2002): the Internet can potentially help to promote AHLs by making them more visible and accessible. It enables effective methods of archiving language data and promoting teaching materials, and can thus support standardization efforts. In an era of mass migration, it can bring together diaspora speakers to create online communities (see, e.g., Androutsopoulos 2006; Karim 2003; Oiarzabal 2012). All the authors cited here also emphasize that each case is different, and deserves to be analysed individually. It is also worth mentioning that not all case studies reported success (Cunliffe and Harries 2005; Reershemius 2010; Sperlich 2005).

Since these studies, technological developments normally summarized as 'Web 2.0', with their emphasis on multimodal content sharing and social networking, have changed communicative practices on the web yet again. These are a huge step 
away from an era when specialists created websites and the user's role was predominantly restricted to that of a recipient and consumer. Within a few years, the new technologies have made the Internet a far more interactive space, where bottomup activities prevail. The resulting

participatory and convergent digital environments are characterized by processes of multimodality and multiauthorship: their content is produced by multiple participants, simultaneously and in part independently of each other, and they host and integrate complex combinations of media and semiotic modes, including written text (and, increasingly, speech), standing image, moving image, color and graphic design. (Androutsopoulos 2011, 281-282)

The present study focuses on Web 2.0 and its interactive potential for individual speakers. The overarching question is whether social network sites have the potential to provide new mediatized spaces for speakers of an AHL. Thus, the study examines communicative practices of AHL - Low German - speakers on the social network site Facebook, motivated by the following questions:

1. How do speakers of Low German create and design mediatized spaces on social media?

2. Is the application of Low German on social media leading to sociolinguistic change?

3. What role does writing in the AHL play in this context?

4. Could the bilingual linguistic practices observed be relevant to processes of language maintenance for a heritage language in the process of language shift?

The study follows an inclusive approach to sociolinguistics that emphasizes the individual speaker, or in this case CMC user, as the agent who applies language to communicate with others in society. CMC in AHLs tends to be bi- or multilingual. Thus, my analysis focuses on language choice (Low German, German, English or other languages), writing in the AHL, the social and communicative contexts in which users apply Low German and the linguistic practices in which speakers use their bi- or multilingual repertoires. I apply the theoretical framework of translanguaging (see, e.g., García 2009; García and Li Wei 2014). 
Analysing communication on Facebook, this study is based on data of asynchronous written communication. The following section gives an overview of Low German as a predominantly spoken variety and the challenges faced by speakers when using it for writing purposes. The data collection and methodology for the study are then described, followed by the analysis, which focuses on bilingual writing practices in the AHL.

\section{Speaking and writing an autochthonous heritage language in the twenty-first century: The example of Low German}

Low German speakers currently number approximately 2.6 million, mainly in northern Germany. This number is based on two surveys, conducted in 1984 and 2005 (Möller 2008). The 2005 survey shows that the number of competent speakers of Low German has declined by more than 50 per cent within 23 years. The Low German varieties were recognized as an endangered regional language as part of the European Charter for Regional or Minority Languages in 1999. Nevertheless, speakers, activists and linguists are still engaged in debates over whether Low German is a language or a dialect (Goltz 2009b).

Speakers of Low German are bi- or multilingual and use their heritage language alongside dominant standard varieties, which for a majority of them is standard German. Like most AHLs, Low German is transmitted predominantly within the family rather than as part of an official education system, although it is reflected in different ways and to different degrees in the educational curricula of the northern German federal Länder (www.ins-bremen.de/de/sprache/bildung/platt-in-derschule.html). For most of its speakers, Low German is a predominantly spoken language, and standard German serves as their only written language. Recent studies have shown that a majority of Low German speakers feel uncomfortable writing in Low German (Möller 2008; Reershemius 2002) - despite the existence of a considerable corpus of literature in Low German since medieval times, to which an active literary scene has added ever since (see, e.g., Stellmacher 2004). Low German served as spoken and written lingua franca for the Hanseatic League between around 1350 and 1550. With the shift of economic and political power towards the south, Low German declined as a written language and developed mainly in spoken form, leading to a sharp increase in dialectal variation. For the period between 1600 and the mid-nineteenth century, hardly any written documents in Low German survive, but as 
part of the Romantic movements of the nineteenth century, Low German was rediscovered by writers and intellectuals, who started to publish novels and poetry in Low German while also working towards a unifying orthographic standard. Due to strong dialectal differences between varieties of Low German and the absence of effective institutional support, these attempts were rather unsuccessful. As a result, the debate on orthography and standards in Low German has continued right up to the present, and a single standardized orthography still does not exist. ${ }^{4}$ There are, however, a number of regional writing conventions available which language activists try to enforce at various levels (Goltz 2009b; Kellner 2002).

For some time, Low German has been in the process of shift towards German due to an increasing loss of communicative domains and decreasing transmission across generations in the family. Although Low German is in steady decline as a vernacular of day-to-day communication, it has become immensely popular (Arendt 2010; Möller 2008; Reershemius 2009) and increasingly visible in public space in recent years (Reershemius 2011a). As a spoken language, Low German is often drawn on to establish proximity and closeness in communication. Low German connects the individual speakers to a concept of place, even if they do not live in the Low German-speaking regions any more. It is used as part of speakers' identity construction, and in addition to communicative functions, it also increasingly serves symbolic or post-vernacular purposes (Edwards 2004; Gardner-Chloros 2009; Reershemius 2009). Low German tends to be associated with an ideology of tradition and authenticity, making it subject to commodification processes, for example in the context of tourism (Heller 2003; Jaworski and Pritchard 2005; Pietikäinen and KellyHolmes 2011; Reershemius 2011a, 2011b). Low German speakers have created Internet spaces dedicated to their heritage language (Andresen 2008; Reershemius 2010; Zurawski 2007). However, the Low German web outside the domains of social media is dominated by a small but active scene of individuals and organizations promoting Low German language and culture, predominantly in the areas of amateur theatre, music, poetry, literature, and language maintenance. These websites confirm observations that the major functions of Low German in the present are shifting to entertainment, performance and identity construction (Peters 1998; Reershemius 2009; Schröder 1997), again in line with the majority of AHLs. Outside the sphere of social media, the Low German web is generally not interactive, but very much used as 
a digital poster board for activities of the Low German culture scene (Reershemius 2010).

The features listed thus far for Low German in the twenty-first century indicate that it can be regarded as a representative example of an AHL, especially in the European context. The following section sets out the data and methodology of the research undertaken for this study.

\section{Data and methodology}

The study is based on a six-month period of online observation, carried out between September 2013 and February 2014. It was conducted using methods of online ethnography (Androutsopoulos 2008, 2013; Androutsopoulos et al. 2013; Hine 2000). This involves blended data collection: gathering screen-based and user-based data through observation during regular visits to selected social networking sites; collecting screen data; and subsequently establishing contact with a sample of participants (Androutsopoulos 2013, 240-243). All activities related to Low German on the social network site Facebook were observed for a period of six months as far as they were publicly accessible. ${ }^{5}$ Facebook was chosen because it is the most popular social network site worldwide (http://www.pewinternet.org/fact-sheets/socialnetworking-fact-sheet/). Social network sites such as Facebook can be distinguished from other social media by a number of special features. ${ }^{6}$ For example, users create their own profiles, public or partly public, and compile a list of 'friends' to interact with. These lists are normally open to all participants within the social network, and can be used as a basis to expand the individual user's own networks (boyd and Ellison 2008). Facebook also allows its users to set up topical 'groups' as forums for them to share their interest in a common theme, with discussion or posting relevant content. Creators of such groups can decide whether they want them to be publicly available for all Facebook users ('open') or keep them private ('closed'), restricting participation to invited 'friends'. For the purpose of this study, all Facebook groups dealing with the topic of Low German were initially chosen as potential data, since they can provide active forums for Low German speakers to communicate.

During the observation period, there were 51 Facebook groups dedicated in some form or another to Low German. ${ }^{7}$ Eighteen of them have fewer than four members, and were not taken into consideration in the following analysis. Of the remaining 33 groups, 11 are dedicated to Low German theatre, with the number of 
members ranging from four (Plattdeutsche Laienspielschar Nottuln e.V.) to 262 (Plattdeutsches Theater Metelen). Interaction within these groups focuses on theatrical productions and their organization, as is to be expected. It can be intense and frequent at times and then rather quiet for several weeks, and it is mostly carried out in German. Of the remaining 22 groups, many cover Low German for particular regions such as Hamburg or Schleswig-Holstein, Low German as a language of the church, or Low German and music (see Table 1).

Table 1: Low German 'groups' on Facebook in order of size (min. 4 members)

\begin{tabular}{|c|c|c|}
\hline Group name & Members & Open / closed \\
\hline Lustige plattdeutsche Wörter & 1235 & Open \\
\hline Wi proten Platt & 490 & Open \\
\hline $\begin{array}{l}\text { Vergessene plattdeutsche Wörter und } \\
\text { Sprüche }\end{array}$ & 474 & Closed \\
\hline Language survey: Umfrage Plattdeutsch & 341 & Open \\
\hline Plattdeutsch - the language of champions & 313 & Open \\
\hline Theatre: Plattdeutsches Theater Metelen & 262 & Open \\
\hline $\begin{array}{l}\text { Music: Der erste plattdeutsche Song in den } \\
\text { Charts }\end{array}$ & 207 & Open \\
\hline Platt für Anfänger und Fortgeschrittene & 172 & Open \\
\hline $\begin{array}{l}\text { Regional Low German: Plattdeutsch- } \\
\text { Plattform Hamburg }\end{array}$ & 112 & Open \\
\hline Theatre: Plattdeutsches Theater Gescher & 67 & Open \\
\hline Theatre: Ik speel plattdütsk Theater & 67 & Open \\
\hline $\begin{array}{l}\text { Regional Low German: Plattdüütsch ut } \\
\text { Schleswig-Holstein }\end{array}$ & 58 & Closed \\
\hline Church: Plattdüütsch in de Kaark & 58 & Open \\
\hline Plattdüütsche Jungs & 56 & Closed \\
\hline $\begin{array}{l}\text { Theatre: Plattdeutsche und hochdeutsche } \\
\text { Theaterstücke }\end{array}$ & 45 & Open \\
\hline $\begin{array}{l}\text { Regional Low German: Plattdütsk in } \\
\text { Ostfreesland }\end{array}$ & 31 & Open \\
\hline $\begin{array}{l}\text { Theatre: Niederdeutsche Bühne Buchholz } \\
\text { 'De Steenbeeker' }\end{array}$ & 27 & Closed \\
\hline $\begin{array}{l}\text { Theatre: Borkumer Niederdeutsche Bühne } \\
\text { (BNB) }\end{array}$ & 25 & Closed \\
\hline
\end{tabular}




\begin{tabular}{|l|r|c|}
\hline Theatre: Plattdeutsche Laienspielgruppe & 24 & Closed \\
Hahlen & 17 & Open \\
\hline Plattdüütsch Geprüt & 17 & Open \\
\hline Plattdüütsch Lüüd & 16 & Closed \\
\hline Theatre: Niederdeutsche Bühne Flensburg & 14 & Open \\
\hline Wi schnackt Platt! Zweitsprache Plattdeutsch & 13 & Open \\
\hline L2: Platt & 13 & Open \\
\hline $\begin{array}{l}\text { Theatre: Niederdeutsche Bühne Münster (in } \\
\text { German) }\end{array}$ & 9 & Open \\
\hline $\begin{array}{l}\text { Theatre: Niederdeutsche Bühne Norden (in } \\
\text { German) }\end{array}$ & 8 & Open \\
\hline Wunnerbares Plattdüütsch & 7 & Open \\
\hline Low German / Plattdeutsch & 5 & Open \\
\hline Plattdeutsche abende & 5 & Open \\
\hline Plattdüütsche stammdisch berlin & 5 & Closed \\
\hline Niederdeutsch AG & 4 & Closed \\
\hline $\begin{array}{l}\text { Theatre: Plattdeutsche Laienspielschar } \\
\text { Nottuln e.V. }\end{array}$ & & Closed \\
\hline Niederdeutsch in Sachsen-Anhalt rocks & & \\
\hline Total: 33 & & \\
\hline
\end{tabular}

Total: 33

As a basis for this article, the Low German Facebook group with the largest number of subscribers was chosen for a detailed analysis, which included weekly online observation, taking regular ethnographic field notes, collecting screen data and analysing Facebook user profiles as far as these were publicly accessible. The data collected was analysed with a mixed approach, combining quantitative and qualitative methods (Androutsopoulos and Ziegler 2004). After four months of observation, six users who fit the average profile were contacted via Facebook's message function. The integration of user-based data allows the study to contextualize the screen-based data within a wider socio-cultural background (Androutsopoulos 2013, 240). The users were invited to view the researcher's own Facebook profile, informed about the aims and objectives of the study, and asked whether they would agree to write about their individual linguistic biographies and their linguistic practices within and outside Facebook. They were informed that the research would comply with the ethics 
guidelines of the Association of Internet Researchers (http://aoirethics.ijire.net), for example in relation to anonymization of names and profiles.

\section{Low German on Facebook}

The list of Facebook groups in Table 1 shows that Low German is a topic and area of activity on Facebook. In many cases, the topical foci of Facebook's Low German groups reflect those of the Low German web outside social media as outlined above. This also applies indirectly to two of the largest groups, which can be described as forums for amateur lexicographers in the widest sense: Lustige plattdeutsche Wörter 'Funny words in Low German' (1235 members, open) and Vergessene plattdeutsche Wörter und Sprüche 'Forgotten words and sayings in Low German' (475 members, closed). Goltz (2009a) has noted the proliferation of Low German online dictionaries and word collections on the Internet. Institutions and individuals provide opportunities for users to contribute Low German words and phrases, and these opportunities are taken up enthusiastically. Goltz counted nine such word collections for Low German; six months later Reershemius (2010) found 13. While some of the collections use the data gathered in this way to modernize Low German vocabulary in a professional lexicographic manner - for example the inslex project, run by the Institute for Low German Language (INS) in Bremen - most are set up by individuals as part of personal blogs or websites, and are driven by a different motivation: they endeavour to preserve 'old' words and phrases which users may remember from their parents or grandparents. Word-collecting activities suggest an active contribution to maintenance efforts. To participate, the individual user does not necessarily need to be a competent speaker; it is sufficient to remember the odd word here and there. Thus, word collecting can be categorized as a 'post-vernacular' practice (Reershemius 2009; Shandler 2005), typical of communities of AHL speakers. Furthermore, the collections celebrate linguistic heritage while also providing a source of entertainment. $^{8}$

The Facebook group Lustige plattdeutsche Wörter (LPW, 'Funny words in Low German') works according to the same principles as the Internet online dictionaries and word lists. It encourages other Facebook users to contribute Low German words, but with the additional opportunity to share and discuss them with others. LPW turns out to be by far the most popular of all the groups related to Low German. It was set up by a professional musician from northern Germany in 
September 2012. During its first year of existence, interaction was busier than during the period of observation. Even so, between September 2013 and February 2014 frequent communication could be observed, with an average of 21 events per month initiated by group members. ${ }^{9}$

\section{Who participates in LPW?}

Research on user profiles cannot be exact, since not all users disclose the same level of information about themselves and not all of it is necessarily founded in reality (boyd 2010), so the following overview must be regarded as a rough sketch. Members of LPW who took part in interactions during the period of observation were approximately 50 per cent male and 50 per cent female and seem to cover different age groups, but with a high representation of middle-aged users. Geographically, they were based in various parts of the Low German language areas and beyond - although predominantly from within Germany and with a clear regional focus on East Frisia, a region in north-west Germany, bordering the Netherlands, where many active Low German speakers can still be found. Towards the end of the observation period, I contacted six individual members of LPW, regular contributors whose profiles indicate that they are representative of the group as a whole, to obtain their views of LPW, and its activities and to find out more about their personal linguistic background and attitudes.

One of them is R, a woman in her early sixties from East Frisia, chosen because her linguistic biography is typical of the group of users analysed here. It also illustrates the various stages of attitudes towards Low German from within and outside the community of its speakers. R grew up with Low German, but told me that as a child she and her peers were forbidden to use it at primary school by their teacher, who did not speak the language. Later she married, and since her husband did not speak Low German they raised their children in German only. She also mentioned that at the time it was deemed to be of utmost importance that children spoke 'good' German. She now regrets that she did not raise her children with Low German, and hopes that her grandchildren will be taught some at school. R posts frequently on Facebook; LPW is one of 20 groups she belongs to, two of which are related to Low German. 
Table 2 shows the general distribution of activity types in LPW during the period of observation.

Table 2: Distribution of activity types in LPW (September 2013 to February 2014)

\begin{tabular}{|r|l|r|}
\hline 1 & 'Do you know the Low German word / phrase XYZ?' & $36 \%$ \\
\hline 2 & Presentation of pictures (photographs, drawings, etc.) & $18 \%$ \\
\hline 3 & Presentation of texts in Low German (e.g. jokes or poems) & $15 \%$ \\
\hline 4 & Presentation of video clips & $11 \%$ \\
\hline 5 & Presentation of audio clips & $5 \%$ \\
\hline 6 & Information about an event (e.g. concerts, theatre productions, etc.) & $4 \%$ \\
\hline 7 & Presentation of links & $4 \%$ \\
\hline 8 & Miscellaneous others & $25 \%$ \\
\hline
\end{tabular}

The dominant communicative activity in LPW is the first one listed in Table 2: a member of the group initiates an event by posting a question, asking whether the group knows a particular word or phrase in Low German. This is not a question in the sense that the initiator does not know the answer - it is intended as a game to test the other members' knowledge. Other group members then offer explanations or translations into German. The initiator normally comments again to indicate whether the other contributors got it right. Example 1 is a typical exchange:

\section{Example 1:}

G: Wat is een blickje? heb ik noch van mien Oma hört.

$\mathrm{H}$ : Dormit mußten wie frauge Melk van Buhr holen.

G: genau, muß ik ok imme.

I: Bi uns heetes dat 'Aker' of 'Bumme'.

J: Melkbuum.

G: What is a 'blickje' [metal container to transport milk]? I heard it from my granny.

$\mathrm{H}$ : We had to fetch milk from the farmer with that.

G: Exactly, I had to, too.

I: In our house it was called 'aker' [synonym for 'blickje'] or 'bumme' [synonym for 'blickje']. 
J: Melkbuum [synonym for 'blickje'].

Example 1 shows that the exchange is not only about finding an answer to the question. It also gives users the opportunity to add their own personal comments, in this case mostly synonyms. It is typical of the exchanges that the initiator - here, user $\mathrm{G}$ - contributes again, now to confirm the right answer. Also representative of the majority of such exchanges is the reference back to the past and childhood memories. G knows the word 'blickje' from his grandmother, $\mathrm{G}$ and $\mathrm{H}$ both used the object as children to collect milk from the farmer, while I and J remember that they used other words at home when they were children.

\section{Writing in Low German on LPW}

The exchange in Example 1 is entirely in Low German, as were 41 per cent of all events in LPW during the period of observation. This is remarkable, since the medium Facebook requires users to write. Lillis and McKinney $(2013,423)$ point out that for most current studies on CMC, written data has been analysed as if it were spoken language. In her analysis of web discussion forums, Kytölä $(2012,109)$ states why CMC should not be treated as a form of spoken language: 'language use in the web forums is most accurately seen as a distinctive form of writing combined with several visual means'. Androutsopoulos (2015) describes language used in CMC as written language partly conceptualized by spoken language but clearly not mirroring it: many contextualization cues available in spoken language do not exist, so that users develop ways and means for alternatives. Based on Mark Sebba's typology of spoken and written genres (Sebba 2012, 7-8), I consider CMC on Facebook a literacy practice that features the following genre markers: +written, -spoken, +interactive, synchronous, +sequential, +semi-permanent. Previous research has shown that the majority of Low German speakers do not write in Low German at all, and that many feel uneasy when it comes to writing in anything other than German (Möller 2008, 40-41; Reershemius 2010, 196-199). The analysis of user profiles of LPW shows that a majority of them are from East Frisia, a region for which a specific set of orthographic rules does exist (Ostfriesische Landschaft 2010) and is adhered to by most authors from the region who write in Low German. However, there is no indication that East Frisian LPW users take any notice of these rules in their posts. They write in Low German as they see fit, usually by roughly applying the phonetic 
principles underlying German standard writing and without any evident or expressed consideration for Low German orthography. It is also remarkably different from a discussion forum - before the advent of Web 2.0 technologies in the Low Germanspeaking communities - analysed in Reershemius (2010,191-201), where speakers of Low German expressed their insecurity over writing while individual forum members tried to implement their versions of Low German orthography quite forcefully, thus intimidating other users and at times preventing the use of Low German altogether. Communication in LPW, in contrast, is relaxed. During the period of observation I did not come across any discussion of orthography; everybody wrote their local variety of Low German in whatever way they preferred.

According to Sebba's model of regulation in what he calls the 'orthographic space' $(2007,43)$, orthography in CMC covers a less regulated space compared with such spaces as publishing or writing in educational contexts. In LPW, only a mild form of self-regulation could be observed. For example, one regular user who applies a particularly idiosyncratic way of writing in Low German never receives comments on his attempts to initiate events, only the odd polite 'like'. By ignoring this contributor, the other group members signal that consensual forms of orthography should be applied, thus ensuring a certain common-sense approach to finding multiple ways of writing in Low German that all users can follow.

Linguistic tolerance in LPW does not only pertain to the area of writing and orthography. In spoken interaction outside CMC, Low German speakers tend to switch immediately to German when they notice that one of their partners in communication is not altogether competent in Low German, and the level of competence that is expected in order to uphold a conversation in Low German tends to be high. The same reaction can be observed when speakers of different Low German varieties come together. Communication in LPW does not follow this pattern: users with a recognizably limited repertoire in Low German are not sanctioned, and users writing in different varieties of Low German also continue to communicate with each other. It could be speculated that the lack of face-to-face contact and the fact that users do not know each other outside Facebook might contribute to this more relaxed attitude. It is an interesting question, if hypothetical at this stage, whether linguistic practices such as these could potentially be transferred back to oral communication. Language shift could more easily be stemmed if a 
greater level of tolerance towards variation prevailed among speakers, since this would increase the number of occasions for communication in Low German.

\section{Translanguaging: Bilingual practices on LPW}

While one of the main motives for communication in LPW is the celebration of linguistic heritage, another is clearly entertainment and humour, as Example 2 illustrates:

\section{Example 2:}

L: wat sergen ji dan tegen 'Leitpfahl'?

M: Nix ... de secht ja ok nix an mi. :)

L: ick sech nix ick foor dran fer bie.

$\mathrm{N}$ : beeter is dat $:$

L: What do you call a 'Leitpfahl' [German: road marking post ]?

Literally: What do you say to a 'Leitpfahl'?

M: Nothing ... it doesn't say anything to me. :)

L: I don't say anything, I drive past it.

$\mathrm{N}$ : That's certainly better. :;

What starts as a typical LPW initiating post - in this case asking for the Low German translation of a German term - turns out to be a joke. The Low German phrase wat sergen ji tegen has the double meaning of 'what do you call a' and 'what do you say to'. This seems to be well known among LPW users, who do not fall into the trap of trying to give translations but respond with the correct answer: you don't talk to a road marking post (user M). The response is confirmed as correct by the initiator $\mathrm{L}$, who adds that you simply drive past it. The exchange in Example 2 shows that LPW users are adept translators between Low German and German and well aware of synonyms and homonyms, which they apply for humour and language play as a form of entertainment. It is quite obvious that both languages, Low German and German, are constantly present in most of the exchanges, even in the ones that seem at first glance to be monolingual. This reflects the linguistic reality of most of the group members, who are bilingual and live with both German and Low German in their day- 
to-day routines, ${ }^{10}$ another feature that Low German speakers share with the majority of AHL speakers (see, e.g., Jaffe 2007 for speakers of Corsican).

While 41 per cent of all the events initiated in the period of observation are in Low German, 20 per cent are in German only and 39 per cent bilingual in Low German and German. Contributors to LPW display a tolerant attitude towards language choice; members are not reprimanded for using German in a group dedicated to Low German. Using both languages within the same exchange is acceptable, even the norm. One of the most surprising results of Reershemius's (2010) pre-Web 2.0 analysis of a Low German discussion forum was that language alternation could rarely be observed. ${ }^{11}$ In the discussion forum analysed, most posts were in German with the odd emblematic use of Low German words or phrases. The few users who wrote in Low German were mainly language activists who did not code-switch, presumably as part of an attempt to keep their Low German 'pure'. Yet, most Low German speakers have an extended - not necessarily balanced - bilingual Low German and German repertoire that they apply according to situation and communicative requirements. ${ }^{12}$ The question must thus be precisely how users apply their bilingual repertoires as part of asynchronous communication in LPW. The following event from LPW (Example 3, German in bold) is representative of the way its users communicate by drawing on their bilingual repertoire in Low German and German:

Example 3:

A: Kenn jie noch stiekelstarn?

B: Jo dat kenn ik! 'Stichlinge' (kleiner Fisch), die haben wir früher immer im Graben gefangen!

A : ich ok !!

C: As kind heb de ok in Schlot fangen un bi mien Goldfischen inschmetten.

Anner Dag wern mien Goldfischen dod!!!

D: ick heeb de mit senke fangen

E: Jau, D, eenmol 400 Stück an een Daag, bi mi achter'd Huus!

A: Do you remember 'stiekelstarn'? 
B: Yes, I do. 'Sticklebacks' (small fish), we used to catch them in ditches.

A: Me too!

C: As a child I also caught them in a ditch and then threw them in with my

goldfish. The next day my goldfish were dead!!!

D: I caught them with a bait net.

E: Yes, D, 400 in one day once, at my place, behind the house!

User A initiates the thread of communication in the established LPW way: he asks in Low German whether other group members know the word stiekelstarn 'sticklebacks'. User B indicates in Low German that he does, and to prove his claim he gives the translation in German, Stichlinge, which triggers him to continue in German and to share with other group members that he used to catch them as a child in ditches. A, the initiator, returns with a short bilingual response ich (German) ok (Low German) thus confirming that B has got the meaning of the word in question right. The exchange then moves back to Low German, as C tells a short anecdote and D and E follow with a particular fishing strategy, the use of a senke, short for German Köderfischsenke 'bait net'. This is a technical angling term for which the Low German dictionaries do not provide an equivalent, so a Low German speaker such as LPW user D borrows it from German and implements it as if it were Low German. Thus, Example 3 contains translation, intrasentential and intersentential codeswitching, and borrowing - an impressive range of multilingual practices.

The various practices in which speakers use their multilingual repertoires have been gathered by recent research under the heading 'translanguaging' (see, e.g., García 2009; García and Li Wei 2014). Since linguists began to analyse multi- or bilingualism as extended repertoires rather than the co-occurrence of two or more language systems in the mind of the same speaker, a number of terms have been coined to describe language use from this new perspective, such as polylingualism (Jørgensen 2008) or metrolingualism (Maher 2010). Translanguaging as defined by García and Li Wei (2014, 36-42) allows the integration of the concepts underlying metrolingualism and polylingualism, which is why the term is chosen here. This approach defines a bilingual speaker as someone who has access to an extended multilingual repertoire that is applied according to the communicative requirements of specific social settings and situations. It is apparent from Examples 2 and 3 that translanguaging is the norm for LPW users when they are in Low German mode. ${ }^{13}$ 
Interestingly, LWP posts in German tend to be predominantly monolingual. This observation confirms for CMC what research such as the project Sprachvariation in Norddeutschland (SIN; www.sin-project.de) has recently stated for spoken language in northern Germany: bilingual speakers hardly ever translanguage when they are in German mode, but do so extensively when they switch to Low German (Schröder 2011). These findings reflect the more restricted ways that speakers use and especially write in German, which is the dominant standard and written language they were taught at school.

\section{Conclusions}

The rise of social media has changed CMC profoundly, and provides potentially new mediatized spaces for speakers of AHLs. While this potential has existed on the Internet for two decades, social media have made a special contribution to new forms of interactivity and participation of users. This article set out to study how users whose bilingual repertoires include an AHL, Low German, apply it on Facebook. Returning to the research questions set out in the introduction, it can be concluded that in this particular case mediatization has indeed led to sociolinguistic change in three areas:

1) The analysis has shown that new literacy practices are developing. Speakers of Low German, who were previously reluctant writers of their AHL, have started to use it on Facebook. Most remarkable is the difference from the preWeb 2.0 discussion forum examined in Reershemius (2010), which at the time was chosen for analysis because it was the most lively and interactive Low German web space. There, the vast majority of users did not write in Low German but about Low German. The discussion forum had been established with language maintenance in mind, so the ideological stakes were high and may have led to the reluctance to contribute in Low German. The Facebook group LPW, in contrast, was established mainly for entertainment purposes, with nostalgic reminiscences going hand in hand with the celebration of linguistic heritage, humour and language play. In terms of orthography, LPW on Facebook has turned out to be a less regulated space even than the discussion forum, which appears to be one of the reasons for its success. 
2) As a user-dominated website that is not dedicated to language maintenance efforts, LPW allows speakers with a repertoire including Low German to transfer bilingual practices from spoken language to CMC. It is probably the very absence of language maintenance aims that allows this to happen in the LPW group: activists and organizations trying to expand the remit of their AHL sometimes tend to prescribe levels of 'purity' for its use that mean it cannot be applied in mediatized spaces in the same ways speakers would use it in spoken language, namely bilingually and by translanguaging with their main contact languages. Interaction in the Facebook group LPW showed users applying their bilingual repertoire creatively by translanguaging. This also indicates that dominant ideologies about languages, according to which one language needs to cover all aspects of communication (see, e.g., Jaffe 2007), are cast into question by bilingual practices on social network sites. The bilingual realities of AHL speakers seem to have found a mediatized space.

3) Users with a Low German repertoire in LPW display a general attitude of tolerance towards others who use a variety of Low German different from their own or who do not show a high level of competence in Low German. This is remarkably different from spoken communicative practices when Low German is used as a vernacular; there, in both cases speakers tend to switch immediately to German.

Turning to the last research question formulated in the introduction, whether linguistic practices on social media such as Facebook are relevant to processes of language maintenance, the answer is a complex and interesting one. Facebook has provided a mediatized space to users with a bilingual repertoire including Low German - a space that goes beyond the framework of institutional maintenance or the Low German culture scene. To a certain extent it seems that users only dare to take up writing in Low German due to the marked absence of any language maintenance ideology or its proponents in LPW. Users get together in a linguistically and ideologically less regulated space for the purposes of entertainment, humour and the celebration of linguistic heritage and regional identity, and develop their own voice by transferring their bilingual practices from spoken language into a new form of writing in the Facebook group. Although this study has looked at a sample of 1235 speakers in an 
overall community of roughly 2.5 million Low German speakers worldwide, the linguistic practices observed in LPW can be counted as a promising beginning.

The simple fact that an AHL like Low German is present not only on the Internet in general but in social network media could increase its appeal for younger generations (see also Fredsted 2015; Westergaard 2015), thus counteracting the image of AHLs as representing predominantly traditions and values from the past. In the changing and fluid environment of the Internet and its social network sites, further observation of these developments is necessary, since demographic developments mean that the fate of AHLs such as Low German could be decided in the very near future.

\section{References}

Andresen, Dieter. 2008. "Virtuelle Diskurse? Bilanz eines Symposions”. Quickborn. Zeitschrift für plattdeutsche Sprache und Literatur 98: 37-45.

Androutsopoulos, Jannis. 2006. "Multilingualism, diaspora, and the internet: codes and identities on German-based diaspora websites". Journal of Sociolinguistics 10: $419-438$.

Androutsopoulos, Jannis. 2008. "Potentials and limitations of discourse-centred online ethnography”. Language@Internet 5.

http://www.languageatinternet.org/articles/2008 (accessed 18 February 2015).

Androutsopoulos, Jannis. 2011. "From variation to heteroglossia in the study of computer-mediated discourse". In Digital discourse. Language in the new media, edited by Crispin Thurlow and Kristine Mroczek, 277-298. Oxford: Oxford University Press.

Androutsopoulos, Jannis. 2013. “Online data collection”. In Data collection in sociolinguistics: Methods and applications, edited by Christine Mallinson, Betty Childs, and Gerard Van Herks, 236-250. London: Routledge. 
Androutsopoulos, Jannis. 2014. "Mediatization and sociolinguistic change: Key concepts, research traditions, open issues". In Mediatization and sociolinguistic change, edited by Jannis Androutsopoulos, 3-48. Berlin: de Gruyter.

Androutsopoulos, Jannis. 2015. "Networked multilingualism: Some language practices on Facebook and their implications". International Journal of Bilingualism 19 (2): 185-205.

Androutsopoulos, Jannis, and Evelyn Ziegler. 2004. "Exploring language variation on the Internet". In Language variation in Europe, edited by Britt-Louise Gunnarsson, Lena Bergström, Gerd Eklund, Staffan Fridell, Lise H. Hansen, Angela Karstadt, Bengt Nordberg, Eva Sundgrenand, and Mats Thelander, 99-111. Uppsala: Universitetstryckeriet.

Androutsopoulos, Jannis, Yin Feng Hsieh, Joanna Kouzina, and Reyhan Sahin. 2013. "Vernetzte Mehrsprachigkeit auf Facebook: Drei Hamburger Fallstudien”. In Mehrsprachige Kommunikation in der Stadt. Das Beispiel Hamburg, edited by Angelika Redder, Julia Pauli, Roland Kießling, Kristin Bührig, Bernhard Brehmer, Ingrid Breckner, and Jannis Androutsopoulos, 161-197. Münster: Waxmann.

Arendt, Birte. 2010. Niederdeutschdiskurse. Spracheinstellungen im Kontext von Laien, Printmedien und Politik. Berlin: Schmidt.

Blommaert, Jan. 2005. Discourse. Cambridge: Cambridge University Press.

boyd, danah. 2010. "Social network sites as networked publics: Affordances, dynamics, and implications". In Networked self: Identity, community, and culture on social network sites, edited by Zizi Papacharissi, 39-58. London: Routledge.

boyd, danah, and Nicole Ellison. 2008. "Social network sites: Definition, history, and scholarship". Journal of Computer-Mediated Communication 13: 210-230. 
Buszard-Welcher, Laura. 2001. "Can the Web help save my language?” In The Green Book of language revitalization in practice: Towards a sustainable world, edited by Leanne Hinton, and Kenneth Hale, 331-348. San Diego: Academic Press.

Chambers, Jack K. 1998. "TV makes people sound the same”. In Language Myths, edited by Laurie Bauer and Peter Trudgill, 123-131. London: Penguin.

Cormack, Mike. 2007. "The media and language maintenance". In Minority language media: Concepts, critiques and case studies, edited by Mike Cormack and Nancy Hourigan, 52-68. Clevedon, UK: Multilingual Matters.

Coupland, Nikolas. 2014. "Sociolinguistic change, vernacularization and broadcast British media". In Mediatization and sociolinguistic change, edited by Jannis Androutsopoulos, 67-96. Berlin: de Gruyter.

Crystal, David. 2000. Language death. Cambridge: Cambridge University Press.

Cunliffe, Daniel, and Susan C. Herring. 2005. "Introduction to minority languages, multimedia and the web". New Review of Hypermedia and Multimedia 11 (2): 131137.

Cunliffe, Daniel, and Rhys Harries. 2005. "Promoting minority-language use in a bilingual online community". New Review of Hypermedia and Multimedia 11 (2): $157-179$.

Deuber, Dagmar, and Lars Hinrichs. 2007. "Dynamics of orthographic standardization in Jamaican Creole and Nigerian Pidgin". World Englishes 26: 22-47.

Deumert, Ana. 2014. "Sites of struggle and possibility in cyperspace. Wikipedia and Facebook in Afrika". In Mediatization and sociolinguistic change, edited by Jannis Androutsopoulos, 487-514. Berlin: de Gruyter.

Edwards, John. 2004. "Language minorities". In Handbook of applied linguistics, edited by Alan Davies and Catherine Elder, 451-476. Oxford: Blackwell. 
Eisenlohr, Patrick. 2004. "Language revitalization and new technologies: Cultures of electronic mediation and the refiguring of communities". Annual Review of Anthropology 33: 21-35.

Fishman, Joshua A. 1991. Reversing language shift. Clevedon: Multilingual Matters.

Fredsted, Elin. 2015. "Mündlichkeit und Schriftlichkeit”. In Modernisierung in kleinen und regionalen Sprachen, edited by Elin Fredsted, 1-32. Hildesheim: Olms.

García, Ofelia. 2009. Bilingual education in the 21st century: A global perspective. Oxford: Wiley-Blackwell.

García, Ofelia, and Li Wei. 2014. Translanguaging: Language, bilingualism and education. Basingstoke: Palgrave Macmillan.

Gardner-Chloros, Penelope. 2009. "Multilingualism of autochthonous minorities". In Handbook of multilingualism and multilingual communication, edited by Peter Auer and Li Wei, 469-491. Berlin: Mouton de Gruyter.

Goltz, Reinhard. 2009a. "Plattdeutsche Wortlisten im Internet. Eine Bestandsaufnahme". Quickborn. Zeitschrift für plattdeutsche Sprache und Literatur 99: 45-52.

Goltz, Reinhard. 2009b. "Niederdeutsch: vom wenig einheitlichen Profil einer bedrohten Regionalsprache". In Neben deutsch. Die autochthonen Minderheiten- und Regionalsprachen Deutschlands, edited by Christel Stolz, 59-86. Bochum: Brockmeyer.

Hansen-Jaax, Dörte. 1995. Transfer bei Diglossie. Synchrone Sprachkontaktphänomene im Niederdeutschen. Hamburg: Kovac.

Heller, Monica. 2003. "Globalization, the new economy and the commodification of language and identity". Journal of Sociolinguistics 7: 473-492. 
Hepp, Andreas. 2014. "Mediatization: A panorama of media and communication research". In Mediatization and sociolinguistic change, edited by Jannis Androutsopoulos, 49-66. Berlin: de Gruyter.

Hine, Christine M. 2000. Virtual ethnography. London: Sage.

Hinton, Leanne, and Kenneth Hale, eds. 2001. The Green Book of language revitalization in practice: Towards a sustainable world. San Diego: Academic Press.

Jaffe, Alexandra. 2007. "Minority language movements". In Bilingualism: A social approach, edited by Monica Heller, 50-70. Basingstoke: Palgrave Macmillan.

Jaworski, Adam, and Annette Pritchard, eds. 2005. Discourse, communication, and tourism. Clevedon, UK: Channel View Publications.

Jones, Rhys James, Daniel Cunliffe, and Zoe R. Honeycutt. 2013. "Twitter and the Welsh language". Journal of Multilingual and Multicultural Development 34 (7): $653-671$.

Jørgensen, Jens Normann. 2008. "Polylingual languaging around and among children and adolescents". International Journal of Multilingualism 5 (3): 161-176.

Karim, H. Karim, ed. 2003. The media of diaspora. London: Routledge.

Kellner, Birgit. 2002. Zwischen Anlehnung und Abgrenzung - orthographische Vereinheitlichung als Problem im Niederdeutschen. Heidelberg: Winter.

Kelly-Holmes, Helen. 2014. "Commentary: Mediatized spaces for minoritized languages: Challenges and opportunities". In Mediatization and sociolinguistic change, edited by Jannis Androutsopoulos, 539-543. Berlin: de Gruyter.

Krotz, Friedrich. 2003. "Metaprozesse sozialen und kulturellen Wandels und die Medien”. Medien Journal 27 (1): 7-19. 
Krotz, Friedrich. 2007. Mediatisierung. Fallstudien zum Wandel von Kommunikation. Wiesbaden: VS.

Krotz, Friedrich. 2009. "Mediatization: A concept with which to grasp media and societal change". In Mediatization: Concept, changes, consequences, edited by Knut Lundby, 19-38. New York: Peter Lang.

Kytölä, Samu. 2012. "Multilingual web discussion forums: theoretical, practical and methodological issues". In Language mixing and code-switching in writing, edited by Mark Sebba, Shahrzad Mahootian, and Carla Jonsson, 106-127. New York:

Routledge.

Labov, William. 2001. Principles of Linguistic Change II: Social Factors. Oxford: Blackwell.

Leggio, Daniele V. 2011. "The Romani Internet: Language codification and identity formation”. Paper presented at the Annual Meeting of the Gypsy Lore Society, 1-3 September 2011, Graz, Austria.

http://romani.humanities.manchester.ac.uk/virtuallibrary/publications.html (accessed 24 February 2015).

Lillis, Theresa, and Carolyn McKinney. 2013. "The sociolinguistics of writing in a global context: Objects, lenses, consequences”. Journal of Sociolinguistics 17: 415439.

Maher, John C. 2010. "Metroethnicities and metrolanguages". In The Handbook of Language and Globalization, edited by Nikolas Coupland, 575-591. Oxford: Oxford University Press.

Matras, Yaron. 2013. "Language and the rise of a transnational Romani identity". RomIdent Working Papers (24).

http://romani.humanities.manchester.ac.uk/virtuallibrary/librarydb//web/files/pdfs/379 /Paper24.pdf (accessed 26 June 2015). 
Mensching, Guido. 2000. "The internet as a rescue tool of endangered languages:

Sardinian". Paper presented at the conference Multimedia and minority languages in San Sebastian, 8-9 November 2000. http://www.gaia.es/multilinguae/pdf/Guido.PDF (accessed 18 February 2015).

Möller, Freerk. 2008. Plattdeutsch im 21. Jahrhundert. Bestandsaufnahmen und Perspektiven. Leer: Schuster.

Moriarty, Mairéad. 2014. "Súil Eile. Media, sociolinguistic change and the Irish language”. In Mediatization and sociolinguistic change, edited by Jannis Androutsopoulos, 463-486. Berlin: de Gruyter.

Moring, Tom. 2013. "Media markets and minority languages in the digital age". Journal of Ethnopolitics and Minority Issues in Europe 12 (4): 34-55.

Oiarzabal, Pedro J. 2012. "Diaspora Basques and online social networks: An analysis of users of Basque institutional diaspora groups on Facebook". Journal of Ethnic and Migration Studies 38: 1469-1485.

Ouakrime, Mohamed. 2001. "Promoting the maintenance of endangered languages through the internet: The case of Tamazight". In Endangered languages and the media: Proceedings of the Fifth FEL Conference (Agadir, Morocco, 20-23 September 2001), edited by Chris Moseley, Nicholas Ostler, and Hassan Ouzzate, 6167. Bath: FEL.

Ostfriesische Landschaft, ed. 2010. Schreibregeln für das ostfriesische Niederdeutsch. Revised version.

http://www.ostfriesischelandschaft.de/fileadmin/user_upload/PLATTDEUTSCHBUE RO/TEXTDATEIEN/Schrievregels_neei.pdf (accessed 10 March 2015).

Papacharissi, Zizi. 2009. "The virtual geographies of social networks: A comparative analysis of Facebook, LinkedIn and ASmallWorld". New Media and Society 11: 199220. 
Pietikäinen, Sari. 2014. “Circulation of indigenous Sámi resources across media spaces: A rhizomatic discourse approach". In Mediatization and sociolinguistic change, edited by Jannis Androutsopoulos, 515-538. Berlin: de Gruyter.

Pietikäinen, Sari, and Helen Kelly-Holmes. 2011. "The local political economy of languages in a Sami tourism destination: Authenticity and mobility in the labelling of souvenirs". Journal of Sociolinguistics 15: 323-346.

Peters, Robert. 1998. "Zur Sprachgeschichte des niederdeutschen Raumes”. Zeitschrift für deutsche Philologie 117: 108-127.

Rajah-Carrim, Aaliyah. 2009. "Use and standardization of Mauritian Creole in electronically mediated communication". Journal of Computer-Mediated Communication 14: 484-508.

Reershemius, Gertrud. 2002. "Bilingualismus oder Sprachverlust? Zur Lage und zur aktiven Verwendung des Niederdeutschen in Ostfriesland am Beispiel einer Dorfgemeinschaft”. Zeitschrift für Dialektologie und Linguistik 69 (2): 163-181.

Reershemius, Gertrud. 2009. "Post-vernacular language use in a Low German linguistic community”. Journal of Germanic Linguistics 21: 131-147.

Reershemius, Gertrud. 2010. "Niederdeutsch im Internet. Möglichkeiten und Grenzen computervermittelter Kommunikation für den Spracherhalt". Zeitschrift für Dialektologie und Linguistik 77: 183-206.

Reershemius, Gertrud. 2011a. "Reconstructing the past? The role of Low German in creating linguistic landscapes and linguascapes". Journal of Multilingual and Multicultural Development 32: 33-54. 
Reershemius, Gertrud. 2011b. “A new role for Low German? Language insertion as bilingual practice in the process of language shift". Journal of Sociolinguistics 15 (3): 388-397.

Schröder, Ingrid. 1997. "Niederdeutsch im Kontext der Sprachpolitik". Zeitschrift für germanistische Linguistik 25: 200-206.

Schröder, Ingrid. 2011. "Dialekte im Kontakt. Individuelle Ausformungen des Sprachrepertoires”. Osnabrücker Beiträge zur Sprachtheorie 78: 37-56.

Sebba, Mark. 2007. Spelling and society. Cambridge: Cambridge University Press.

Sebba, Mark. 2012. "Researching and theorising multilingual texts". In Language mixing and code-switching in writing, edited by Mark Sebba, Shahrzad Mahootian, and Carla Jonsson, 1-26. New York: Routledge.

Sebba, Mark. 2013. "Multilingualism in written discourse: An approach to the analysis of multilingual texts". International Journal of Bilingualism 17: 97-118.

Seargeant, Philip, Caroline Tagg, and Wipapan Ngampramuan. 2012. "Language choice and addressivity strategies in Thai English social network interactions". Journal of Sociolinguistics 16: 510-531.

Sharma, Bal Krishna. 2012. "Beyond social networking: Performing global Englishes in Facebook by college youth in Nepal". Journal of Sociolinguistics 16: 483-509.

Shandler, Jeffrey. 2005. Adventures in Yiddishland: Postvernacular language and culture. Berkeley: University of California Press.

Sperlich, Wolfgang B. 2005. "Will cyberforums save endangered languages? A Niuean case". International Journal of the Sociology of Language 172: 51-77.

Stellmacher, Dieter, ed. 2004. Niederdeutsche Sprache und Literatur der Gegenwart. Hildesheim: Olms. 
Thomason, Sarah G. 2015. Endangered languages. Cambridge: Cambridge University Press.

Warschauer, Mark. 2002. "Languages.com. The internet and linguistic pluralism". In Silicon literacies: Communication, innovation and education in the electronic age, edited by Ilana Snyder, 62-74. London: Routledge.

Warschauer, Mark, Ghada R. El Said, and Ayman G. Zohry. 2002. "Language choice online: Globalization and identity in Egypt”. Journal of Computer-Mediated Communication 7. http://onlinelibrary.wiley.com/enhanced/doi/10.1111/j.10836101.2002.tb00157.x (accessed 21 February 2015).

West, Laura, and Anna Marie Trester. 2013. "Facework on Facebook. Conversations on social media”. In Discourse 2.0: Language and new media, edited by Deborah Tannen and Anna Marie Trester, 133-154. Washington, DC: Georgetown University Press.

Westergaard, Astrid. 2015. "Revitalisierung von Dialekt in den neuen Medien”. In Modernisierung in kleinen und regionalen Sprachen, edited by Elin Fredsted, 33-52. Hildesheim: Olms.

Wiens, Peter. 2000. "Russian German Mennonites around the world join efforts in the web to save their mother tongue". Paper presented at the conference Multimedia and minority languages in San Sebastian, 8-9 November 2000.

http://www.gaia.es/multilinguae/pdf/PeterWiens.PDF (accessed 19 February 2015).

Williams, Indigo. 2002. “Downloading heritage: Vietnamese diaspora online”. Paper presented at the conference Media in transition: globalization and convergence, 1012 May 2002. Massachusetts Institute of Technology, Cambridge, MA. H (accessed 22 February 2015).

Zurawski, Nils. 2007. "Plattdeutsch digital: Formen der Sprach- und Identitätskonstruktionen im Internet”. In Kulturraum und Sprachbilder: Plattdeutsch 
gestern und morgen, edited by Institut für niederdeutsche Sprache and Vereinigung Quickborn, 147-166. Leer: Schuster.

\section{Notes}

${ }^{1}$ In studies and articles within and outside the area of linguistics, the term 'the media' is often applied rather vaguely and sweepingly to a wide range of different forms and genres, but normally print and broadcast media (see, e.g., Androutsopoulos 2014).

${ }^{2}$ Low German is the English name for Platt or Plattdütsch, as the language is referred to by its speakers. In standard German it is Plattdeutsch or Niederdeutsch.

Plautdietsch is used to refer to the varieties spoken by the Mennonite communities across the world. The term 'language' is applied here as a sociolinguistic term. This means that entities such as 'English', 'French', 'Russian', or in this case 'Low German' and 'German', are seen as umbrella terms for 'complex and layered collections of language varieties' (Blommaert 2005, 10).

3 There is uncertainty among linguists and language activists as to what term to use to describe the languages I refer to as AHLs (see Cunliffe and Herring 2005, 133).The European Charter for Regional and Minority Languages (ECRML), for example, uses the term regional and minority languages. My use of AHL instead is based on many years of linguistic fieldwork among speakers of Yiddish and Low German, which have convinced me that speakers do not necessarily see themselves as part of a minority, but rather as a group sharing a common heritage as well as cultural and linguistic practices.

${ }^{4}$ For a comprehensive overview of standardization and orthography in Low German, see Kellner (2002).

${ }^{5}$ Not included were the Plautdietsch Facebook activities initiated by the international Mennonite communities, which form very specific communities of CMC users that deserve to be looked at separately (see, e.g., Wiens 2000).

${ }^{6}$ Research analysing communication on Facebook is still in its infancy, but is growing rapidly. See,for example, Androutsopoulos (2015); Androutsopoulos et al. (2013); Deumert 2014; Papacharissi (2009); Seargeant, Tagg and Ngampramuan (2012); Sharma (2012); West and Trester (2013). 
${ }^{7}$ In addition, there are 12 groups listed for 'Plautdietsch' or 'Plattdeutsch \& Mennonite Culture', which stand for the variety of Low German spoken by the international Mennonite community (see note 5).

${ }^{8}$ According to Buszard-Welcher (2001), online dictionaries are an integral part of websites dedicated to the maintenance of endangered languages. Indeed, the popularity of online word collections and dictionaries may almost be seen as an indicator of the level of threat to a particular language (Goltz 2009a).

${ }^{9}$ An 'event' is a multi-authored sequence of user posts (Androutsopoulos 2015).

${ }^{10}$ I refer here to a dynamic model of bilingualism as outlined in García and Li Wei (2014, 13-16): a bilingual speaker is not two monolinguals in one person, but someone with an extended repertoire that exceeds one language. This repertoire is not necessarily balanced in terms of its distribution across two or more languages; it may be fluid and is applied by bilingual speakers according to communicative requirements and situation.

${ }^{11}$ Mark Sebba states that language alternation in written texts is still under-researched, and points out that the concept of code-switching was developed for spoken language, mainly conversation (Sebba 2012, 2013).

${ }^{12}$ Research over the last few decades has shown that bilingual speakers tend to merge German and Low German lexical and structural features less when they are speaking German than when they are in Low German mode (Hansen-Jaax 1995; Schröder 2011).

${ }^{13}$ These findings confirm the results of Jones, Cunliffe and Honeycutt $(2013,670)$ in relation to the use of Welsh on Twitter: bilingual speakers transfer the way they communicate bilingually in spoken language to the way they communicate - in writing - on Twitter. 